This research aims to simulate structural steel 400 (SS400) material as an alternative material for the electric bus's chassis structure. The kind of the material is low carbon steel. The SS400 material is produced from one of the largest steel mills in Indonesia, considered a local material. The local material used to increase the total domestic content in electric cars in Indonesia could be improved. Generally, the reverse engineering method of the R260 ladder frame type chassis is used to increase the local content in electric vehicles. However, this research used a ladder frame of type SS400 from local material to fulfill the local content of vehicle (EV)-bus chassis with the reverse engineering method. After the model was successfully created using the finite element software, statics analysis was carried out using the von Mises stress and the simulation results' deflection. The meshing process of the chassis structure is carried out in such a way as to assume global contact. Loading was evenly carried out over the two main beam ladder frames totaling $14,200 \mathrm{~kg}$. The elasticity modulus and tensile strength values used for the material are $190 \mathrm{GPa}$ and $480 \mathrm{MPa}$. Furthermore, the support was placed in the mounting position of the front and rear wheel leaf springs at a front, rear overhang, and wheelbase distance of $2,380 \mathrm{~mm}, 3,290 \mathrm{~mm}$, and $6,000 \mathrm{~mm}$. The resulting approach was carried out using a beam model with a two-overhang beam model. The simulation results showed that type $\mathrm{SS} 400$ from the local material obtained a maximum von Mises stress value of 75.8 MPa, deflection of $2.568 \mathrm{~mm}$, and the lowest safety factor of 3.2. Meanwhile, through theoretical calculations, the obtained stress occurred in 72.33 MPa and deflection of 2.594. There is no significant difference between simulation results and theoretical results

Keywords: chassis, ladder frame, von Mises stress, low carbon steel, electric vehicle
UDC 621

DOI: $10.15587 / 1729-4061.2021 .219928$

\section{DEVELOPMENT OF ELECTRIC VEHICLE (EV)-BUS CHASSIS WITH REVERSE ENGINEERING METHOD USING STATIC ANALYSIS}

\author{
Naz a r ud d i n \\ Postgraduate Student** \\ Department of Mechanical Engineering \\ Universitas Riau
}

Jl. Subrantas Km 12, 5 Kec. Tampan, Kotas Pekanbaru, Indonesia, 28293

E-mail: nazaruddin@eng.unri.ac.id

Mohammad Adhitya

Doctor Ingenieurdegree, Lecturer*

Head of Research Center**

E-mail: madhitya@eng.ui.ac.id

Danardono A Sumarsono

Professor*

Advisor**

E-mail: danardon@eng.ui.ac.id

Ghany Heryana

Postgraduate Student**

E-mail: ghany@stt-wastukancana.ac.id

Rolan Siregar

Postgraduate Student**

E-mail: rolansiregar@ft.unsada.ac.id

Sonki Prasety a

Postgraduate Student**

E-mail: sonki.prasetya@mesin.pnj.ac.id

Fuad Zain u ri

Postgraduate Student**

E-mail: fuad.zainuri@mesin.pnj.ac.id

*Mechanical Engineering Department***

**Research Center for Advanced Vehicle (RCAVe)***

$\star * *$ Universitas Indonesia

Jl. Margonda Raya, Pondok Cina, Kecamatan Beji, Kota Depok, Jawa

Barat, Indonesia 16424
Received date 22.12.2020

Accepted date 17.03.2021 Published date 26.04.2021
How to Cite: Nazaruddin, N., Adhitya, M., Sumarsono, D. A., Heryana, G., Siregar, R., Prasetya, S., Zainuri, F. (2021). Development of electric vehicle (EV)-bus chassis with reverse engineering method using static analysis. Eastern-European Journal of Enterprise Technologies, 2 (7 (110)), 15-22. doi: https://doi.org/10.15587/1729-4061.2021.219928

\section{Introduction}

Electric cars developed in Indonesia are based on Presidential Decree No. 55 of 2019. The regulation aims to accelerate the Battery-Based Electric Motor Vehicle Program for Transportation. Furthermore, it is also in the context of energy efficiency and security to obtain clean air quality. Electric cars' use increases energy use efficiency from batteries to wheels by above $77 \%$ compared to hybrid and internal combustion engines (ICE), which is increased by $38 \%$ and
$25 \%$ [1-4]. The high level of electric cars' efficiency is due to the low-level energy loss of energy distribution from the power source to the wheels.

Universitas Indonesia, UI, launched an electric car to commemorate the $52^{\text {nd }}$ anniversary of the Faculty of Engineering UI on Monday $18^{\text {th }}$ July 2017 at the Faculty of Engineering, UI Campus Depok. Four electric vehicles were displayed at this event, namely Bus Electric Vehicle (EV), Makara Electric Vehicle (MEV) 01, City Car MEV 02, and City Car MEV 03. These electric cars are innovations by 
FTUI lecturers and students that are members of the UI Molina Team. The EV bus is a vehicle with 60 passengers, motor power of $120 \mathrm{~kW}$, and $300 \mathrm{Ah}$. In the future, this bus is expected to gradually replace the overall function of the UI yellow bus as an internal transportation tool for the campus [5].

Car chassis is a significant and essential component that supports the axle, wheels, tires, brakes [6]. It is supported by the front and rear wheel suspension systems that assist the steering in adjusting the vehicle's direction [7]. There are many factors to consider while designing heavy vehicle chassis, material selection, strength, stiffness, and weight [8]. The stiffness of ladder frame structure is mostly influenced by the type of beam used, such as type C, I, or others $[9,10]$. The most common material used for ladder frames in steel [11], ASTM A710 Steel, ASTM A302 Alloy Steel and Aluminum Alloy 6063-T6 [12], material Carbon/ Epoxy [13], grey cast iron, AISI4130 alloy steel, and ASTM A710 STEEL GRADE A [14]. Static analysis on ladder frame is used to find the amount of stress and strain that occurs, the magnitude of deflection in the structure, and safety factors to determine whether the material used is adequate for the loads given [15]. Dynamic analysis can also be done on this ladder frame's design to obtain the structure's natural frequency and mode shape [16]. To get weight reduction, ladder frame structure also needs to be done optimizing material use on the structure. The possible areas of material reduction were identified using topology optimization, and the chassis was optimized for minimum weight [11].

The recent study developed in the EV-Bus is about the brake performance of a passenger car based on the temperature in each brake unit [12] and experimental analysis in the test rig to detect the temperature at the surface disc brake rotor using a rubbing thermocouple [17]. The mode shape analysis for the electric bus chassis structure using the reverse-engineering method on the ladder frame has been conducted. The mode shapes are from 1 to 5 , with the lowest frequency of $11.798 \mathrm{~Hz}, 21.009 \mathrm{~Hz}, 23.876 \mathrm{~Hz}$, $30.84 \mathrm{~Hz}$, and $36.463 \mathrm{~Hz}$ [18]. The results of static analysis in addition to producing a shape mode, as has been published, are also used to see stress, deflection and safety factors.

\section{Literature review and problem statement}

The chassis of a vehicle is the place for various mechanical components, such as the steering system, brakes, axles, engine, tires and so on. Chassis is a vital component of a vehicle as is the backbone in humans. The chassis must guarantee the strength and stability of the vehicle under various conditions. Tie bars that are essential parts of automotive frames are fasteners that bind different auto parts together. There are basically 5 types of designs used for 4 wheeler automobile, they are: 1 - ladder type; 2 -monocoque type; 3 - backbone type; 4 - space type; 5 - combination type.

The research about structural analysis of a ladder chassis frame has studied the chassis of Eicher E2. For this study, chassis was assumed as a simply supported beam with overhang. Pro-E and Ansys software were used for this work. The study also involved the analytical calculation of chassis. Both software analysis and analytical calculation results were compared and found that the stress value obtained from software analysis is $10 \%$ more and also displacement was $5.92 \%$ more [13].

The modeling and structural analysis of heavy vehicle chassis have studied the alternate material for chassis. They studied and analyzed Carbon/Epoxy, E-glass/ Epoxy and $\mathrm{S}$-glass/Epoxy as chassis material in various cross sections like C, I and Box Section. TATA 2515 EX chassis was taken for study. Pro-E and Ansys software were used for this work. The study reveals that the Carbon/Epoxy I section chassis has superior strength, stiffness and lesser weight compared to other materials and cross section [11].

The other research presents stress analysis of a ladder type low loader truck chassis structure consisting of C-beams design for application of 7.5 tones performed by using FEM. The commercial finite element package CATIA version 5 was used for the solution of the problem. To reduce the expenses of the chassis of the trucks, the chassis structure design should be changed or the thickness should be decreased. Also, determination of the stresses of a truck chassis before manufacturing is important due to the design improvement. In order to achieve a reduction in the magnitude of stress at a critical point of the chassis frame, side member thickness, cross member thickness and position of cross member from the rear end were varied [16].

The stress analysis of minibus chassis using finite element method has been performed, case study at Hyundai Cruz Minibus. ABAQUS Software was used for modeling and simulation. Self-weight of the chassis is considered for static analysis and Acceleration, Braking and Road Roughness were considered for dynamic analysis. It was observed that the stresses on chassis caused by braking were greater compared with acceleration [19].

After a careful analysis of various research studies, it has been found that sufficient studies have not been conducted on the variable section chassis concept. This paper has analyzed various literatures. Hence, in order to fill the gap, future research studies may be conducted on the variable section chassis concept in automobiles [20].

This research will simulate the use of the SS400 material as the chassis material of the EV-Bus. The kind of the material is low carbon steel. The SS400 material is produced from one of the largest steel mills in Indonesia, considered a local material. The local material used to increase the total domestic content in electric cars in Indonesia could be improved. This is done because the $\mathrm{EV}$-Bus chassis, which is now converted from the ICE car, is not known with certainty about the material used. The steps taken in this research are reverse engineering to get the shape and model of the existing chassis. Therefore, studies that are devoted to static analysis were carried out to obtain the stress values, deflection and safety factors of this SS400 material. The results of static analysis with CAD software are simply compared with theoretical calculations.

\section{The aim and objectives of the study}

This study aims to find the possibility of using local materials for the EV-Bus chassis. The research follows the government's commitment to increase local content in electric cars in Indonesia. Therefore, to achieve this aim, the following objectives were accomplished: 
- to redesign the chassis structure on this EV Bus with the reverse-engineering method;

- to perform static analysis of the chassis structure to prove SS400 material by taking the load specifications on this type of car by looking at the feasibility of this material from von Mises stress, deflection, and safety factors.

\section{Materials and methods}

\section{1. Reverse Engineering}

Fig. 1 shows that the developed electric bus uses R260 chassis with the reverse engineering method to get the main dimensions.

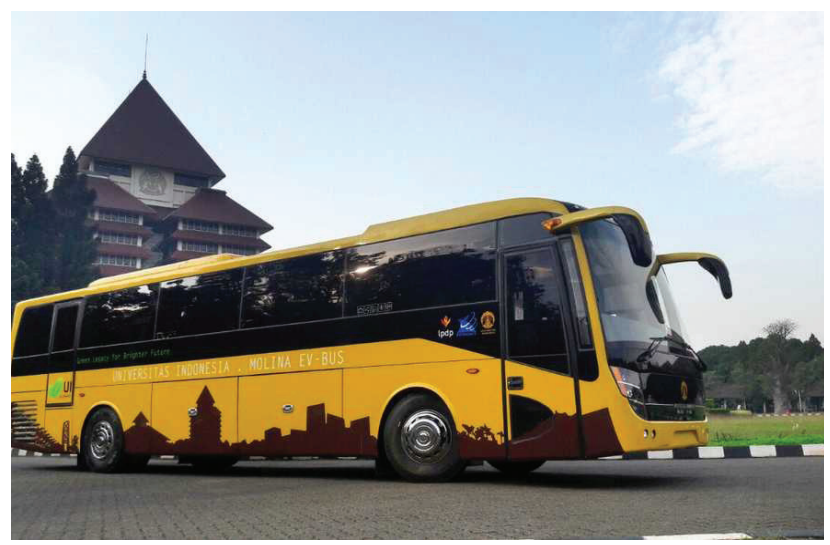

Fig. 1. Universitas Indonesia's Electric Bus

The R260 chassis type is a ladder frame with two main beams, four cross member beams, and two cross pipe beams, as shown in Fig. 2.

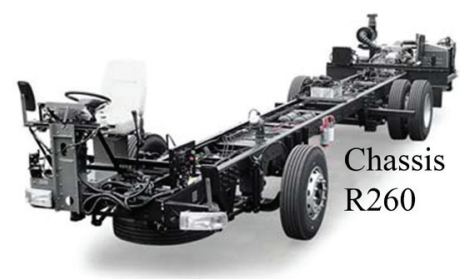

Fig. 2. Rolling Chassis Model of the Electric Bus

Fig. 3 shows that the front overhangs' dimensions are $2,380 \mathrm{~mm}$, the wheelbase is $6,000 \mathrm{~mm}$, and the rear overhang is $3,290 \mathrm{~mm}$.

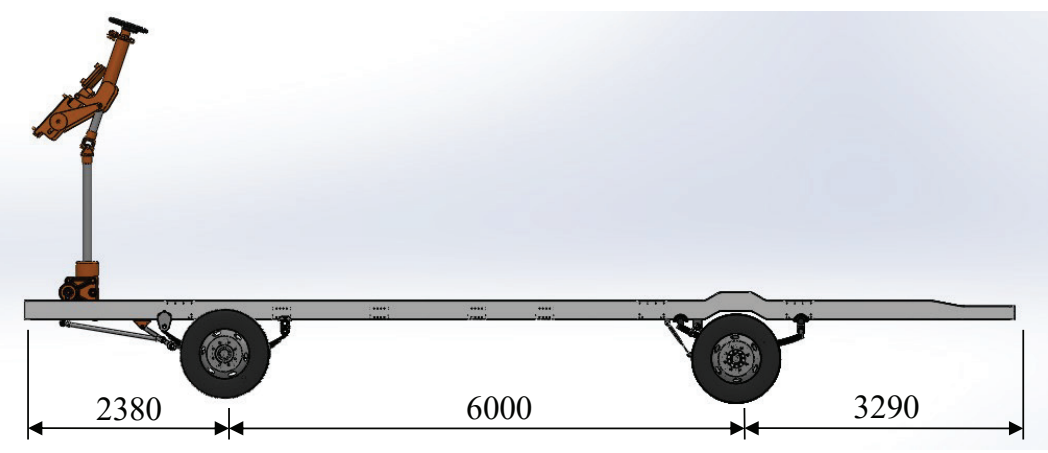

Fig. 3. Primary Dimension of Rolling Chassis Electric Bus
The reverse engineering process is carried out by measuring the main parts of this electric bus chassis, as shown in Fig. 4.

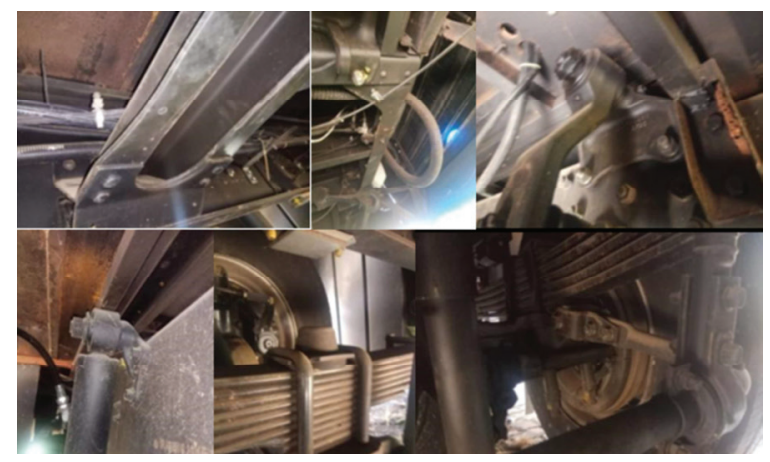

Fig. 4. Rolling chassis parts are measured

\section{2. Static and Theoretical analysis}

From the data in Fig. 4, we have known that the specifications of ladder chassis are:

- wheelbase $(\mathrm{WB})=6,000 \mathrm{~mm}$;

- rear overhang $(\mathrm{ROH})=3,290 \mathrm{~mm}$;

- front overhang $(\mathrm{FOH})=2,380 \mathrm{~mm}$;

- length $=11,670 \mathrm{~mm}$;

- width $=870 \mathrm{~mm}$;

- gross vehicle weight $(\mathrm{GVW})=14,200 \mathrm{~kg}=14.2 \mathrm{ton}=$ $=14.200 \times 9.81=139,302 \mathrm{~N}$.

The chassis has two beams. Therefore, the load acting on each beam is half of the Total load on the chassis. The load acting on the single frame $=139,302 / 2=69,651 \mathrm{~N} /$ Beam. Meanwhile, the Uniformly Distributed Load is $69.651 \mathrm{~N} / 11,670 \mathrm{~mm}=$ $=5.9684 \mathrm{~N} / \mathrm{mm}$.

Fig. 5 shows the distribution of force along with the ladder frame of the EV-Bus chassis seen only two-dimensionally.

The beam with two supports overhangs (Fig. 6) is the nearest modeling to the EV-Bus chassis structure model as shown in Fig. 5 . The $R_{1}$ support reaction is the force held by the car's front wheels, and $R_{2}$ is the force held back by the rear wheels. While the distance between wheel axes is represented by parameter $l$, the front overhang distance is represented by parameter $a$, and the rear overhang distance is represented by parameter $c$. The moment diagram and slide force diagram in Fig. 6 are used to predict the maximum stress and maximum deflection. The equations on the left side of the image will be used as theoretical proof of the simulation results later.

Based on Fig. 6, the following shows that the basic equation is used to calculate the support reaction, the shear force, the moment diagram and the stresses.

The support reaction on the front wheel $\left(R_{C}\right)$ and rear wheel $\left(R_{D}\right)$

$$
\begin{aligned}
& R_{c}=\frac{\omega l(l-2 c)}{2 b}, \\
& R_{D}=\frac{\omega l(l-2 a)}{2 b} .
\end{aligned}
$$

Calculations for shear force and bending moment are as follows:

- shear force:

$$
V_{1}=w a,
$$


$V_{2}=R_{c}-V_{1}$

$V_{4}=w c$

$V_{3}=R_{d}-V_{4}$

- bending moment:

$M_{1}=-\frac{w a^{2}}{2}$,

$M_{2}=-\frac{w c^{2}}{2}$,

$M_{3}=R_{c}\left(\frac{R_{c}}{2 w}-a\right)$
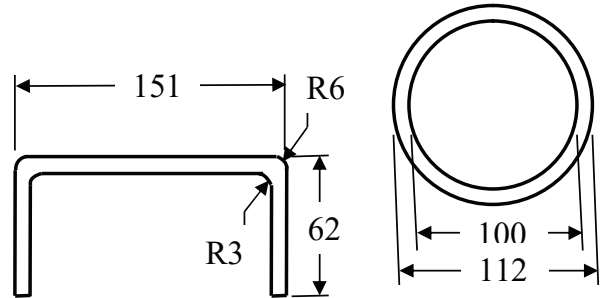

Fig. 8. Cross-section of Cross Member and Hollow Beam

$$
\begin{gathered}
I_{b 3}=\frac{b h^{3}-b_{1} h_{1}^{3}}{12}, \\
I_{b 4}=\frac{\pi\left(d_{o}^{4}-d_{i}^{4}\right)}{64} .
\end{gathered}
$$

$5.9684 \mathrm{~N} / \mathrm{mm}$

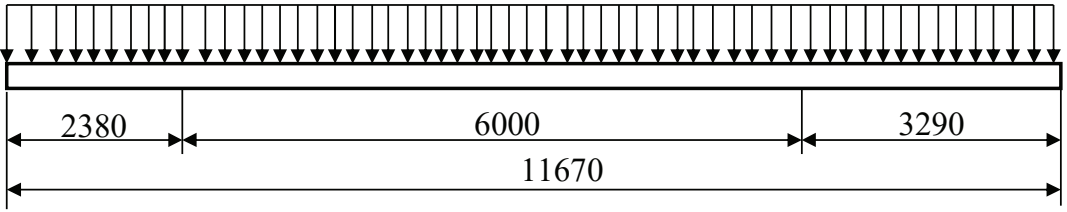

Fig. 5. Distribution Force at EV-Bus Chassis

wl

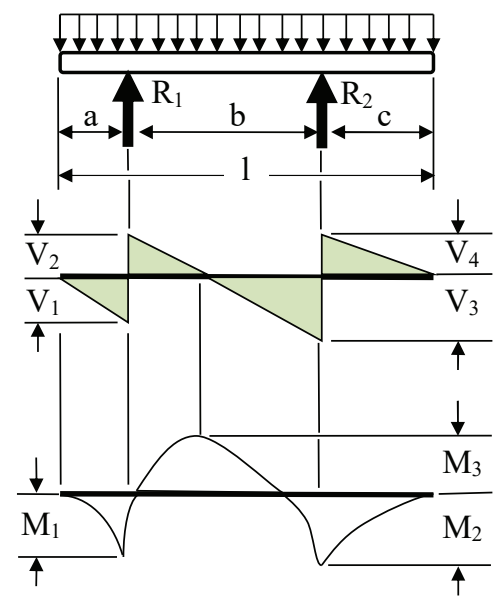

Fig. 6. Beam with two supports and three spans

Inertia Moment on $X-X$-axis.

The moment of inertia for the main beam on the chassis is shown in Fig. 7.

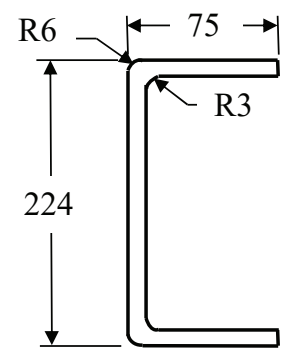

Fig. 7. Cross-section of Main Beam Chassis

$$
I_{x x}=\frac{b h^{3}-b_{1} h_{1}^{3}}{12} \text {. }
$$

The moment of inertia for the cross member beam on the chassis is shown in Fig. 8.
The main stress that occurs in the chassis is as follows

$$
\sigma=\frac{M_{\max } \cdot c}{I_{b t}} .
$$

The deflection of beam overhangs with distributed loads is calculated as follows:

$$
\begin{aligned}
& \text { EI } y=\frac{w}{8}(b+2 a) b x^{2}-\frac{w}{24} x^{4}- \\
& -\frac{w}{16}(b+2 a)^{2} x^{2}+\frac{w b^{2}}{384}\left[24 a^{2}-5 b^{2}\right] .
\end{aligned}
$$

The results obtained in this manual calculation will be considered in selecting materials in simulation with CAD software. The most important value is the stress generated in the equation (13). This value is also a cross-check of the simulation software's values, such as deflection and stress. Accuracy in material selection at the time of simulation and modeling the styles that work on the structure and boundary conditions such as the focus used also affect the simulation's final result.

\section{2. 1. Material Selection}

As a commitment to increase Indonesian electric cars' local content, the material selection is carried out using local content production (made in PT. Krakatau Steel, Indonesia) with SS 400 code. The following are SS 400 material properties from PT. KS and several other sources.

Mechanical Properties:

- elastic (Young's, tensile) modulus: $190 \mathrm{GPa}\left(27 \times 10^{6} \mathrm{psi}\right)$;

- elongation at break: $22 \%$;

- fatigue strength: $200 \mathrm{MPa}\left(29 \times 10^{3} \mathrm{psi}\right)$;

- Poisson's ratio: 0.29;

- shear modulus: $73 \mathrm{GPa}\left(11 \times 10^{6} \mathrm{psi}\right)$;

- shear strength: $300 \mathrm{MPa}\left(44 \times 10^{3} \mathrm{psi}\right.$;

- tensile strength: Ultimate (UTS): $480 \mathrm{MPa}\left(69 \times 10^{3} \mathrm{psi}\right)$;

- tensile strength: Yield (Proof): $290 \mathrm{MPa}\left(41 \times 10^{3} \mathrm{psi}\right)$;

- Brinell hardness: 140.

Thermal Properties:

- Latent Heat of Fusion: $250 \mathrm{~J} / \mathrm{g}$;

- Maximum Temperature: Mechanical: $400{ }^{\circ} \mathrm{C}\left(750{ }^{\circ} \mathrm{F}\right)$;

- Melting Completion (Liquidus): $1,460{ }^{\circ} \mathrm{C}\left(2,670{ }^{\circ} \mathrm{F}\right)$;

- Melting Onset (Solidus): $1,420{ }^{\circ} \mathrm{C}\left(2,590^{\circ} \mathrm{F}\right)$;

- Specific Heat Capacity: $470 \mathrm{~J} / \mathrm{kg}-\mathrm{K}\left(0.11 \mathrm{BTU} / \mathrm{lb}-{ }^{\circ} \mathrm{F}\right)$;

- Thermal Conductivity: $50 \mathrm{~W} / \mathrm{m}-\mathrm{K}\left(29 \mathrm{BTU} / \mathrm{h}-\mathrm{ft}-{ }^{\circ} \mathrm{F}\right)$;

- Thermal Expansion: $11 \mu \mathrm{m} / \mathrm{m}-\mathrm{K}$. 
The process of inputting material properties into the material menu in the CAD software is as Fig. 9.

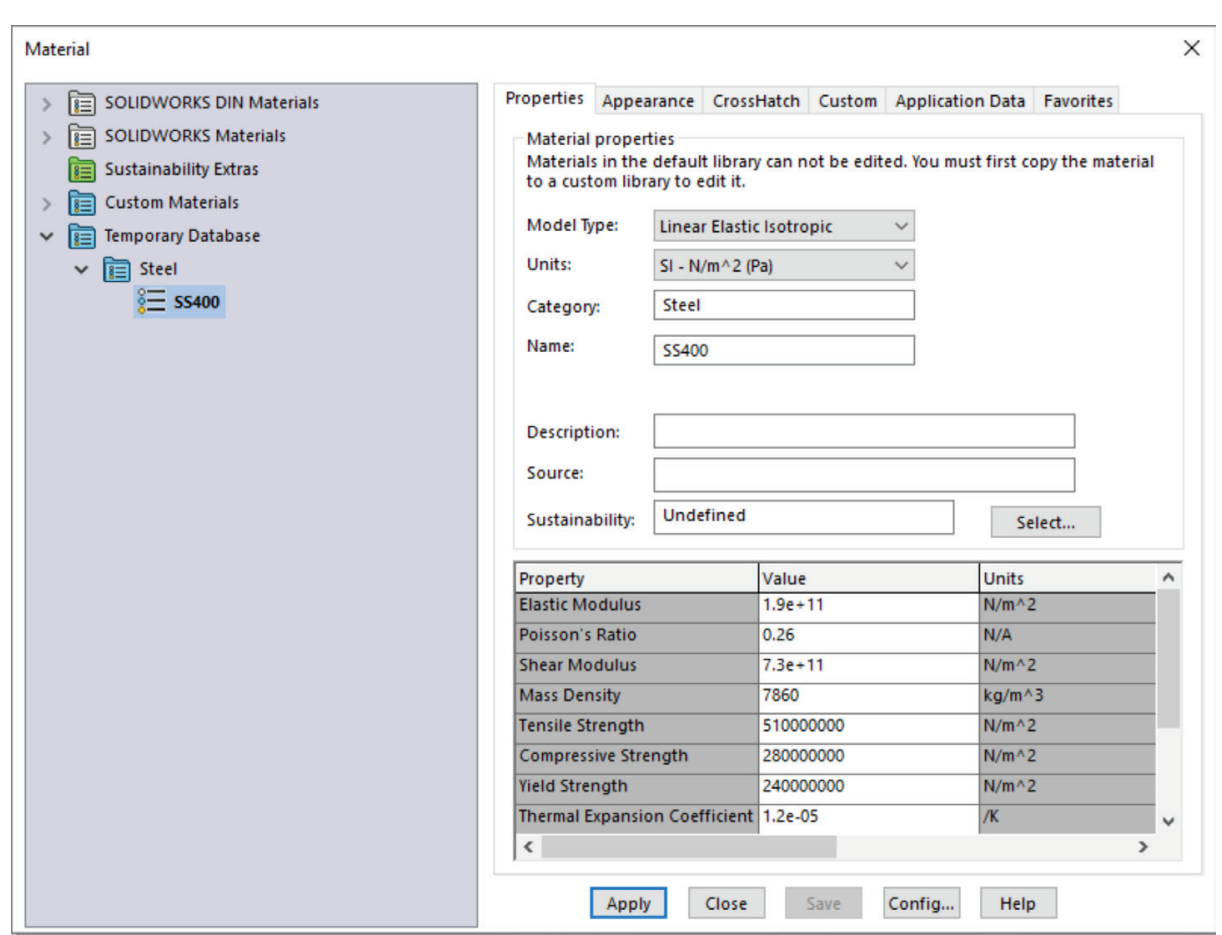

Fig. 9. Material Input of CAD Software

The material properties obtained from the reference are inputted in the material input menu as in Fig. 9. At the top of the menu, the material's general properties are inserted, whether isotropic or non-isotropic and then the unit to be used, whether SI or British, and the last menu is the material's name. At the bottom of the menu is to include essential values of the material's nature, modulus elasticity, Poisson's ratio, shear modulus, tensile strength, yield strength, and so on. These values can then be changed during the simulation if the material used is not desired, such as safety factors. The maximum stress value obtained exceeds the tensile strength value of the material.

\section{2. 2. Chassis Model of Ladder Frame}

From the CAD rolling chassis model in Fig. 9, an analysis is carried out on the ladder frame chassis with the shape as shown in Fig. 11.

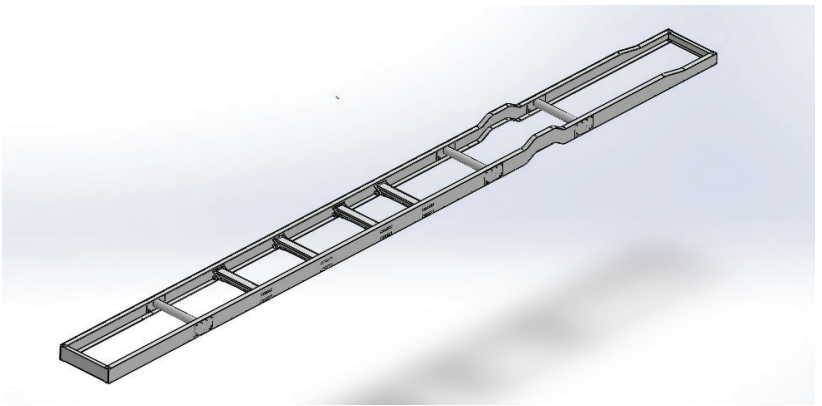

Fig. 10. Model Ladder Frame Chassis EV-Bus

The rolling chassis model of Fig. 11 will be further analyzed in this software by disappearing suspension systems and wheels. The suspension system and wheel are represented with the single force on the chassis resulting in the ladder frame model only as in Fig. 10. This model is idealized as a $2 \mathrm{D}$ beam model as in Fig. 6 . The two main beams are combined with the inertia in Fig. 7 and six cross beams as in Fig. 8. This kind of idealization that will cause theoretical results will be different from simulation software later.

\section{Results of the EV-Bus's Ladder Frame with New Material}

\section{1. Results of Reverse Engineering by Modeling with CAD software}

The dimensions obtained a redraw using CAD software with the following results, as shown in Fig. 9.

The reverse engineering of the re-measured chassis components as in Fig. 4 results in a rolling chassis as Fig. 11. The chassis structure's image will also produce forces modeling on the wheel focus slightly different because the two wheels, front wheel and rear wheel, turned out to be supported by a suspension system. Then inevitably, the wheel's force will be divided into two parts into each wheel's chassis. The design is modeling the forces done on CAD software later.

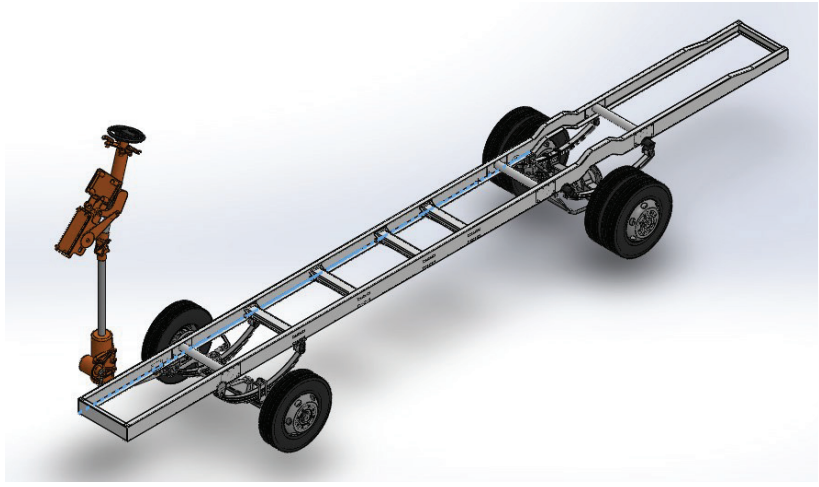

Fig. 11. Rolling Chassis Model with CAD software

5. 2. 1. Determination of Load and Support in Chassis

In Fig. 5, the support was placed on the mounting front-wheel and rear-wheel springs. While the load was in the form of an even distribution along the two main beams of the chassis for a total Gross Vehicle Weight (GVW) of $14,200 \mathrm{~kg}$, according to the specifications of the R260 rolling chassis. Fig. 12 shows the support and the load in CAD modeling.

Fig. 12 shows the distribution force as shown in Fig. 6 . The distributed load is indicated by a downward pink arrow on the two main beams. The suspension system's support on the ladder frame chassis is held with green arrows on the front and rear in this figure. The brown arrow at the center position of this chassis is a heavy load of this chassis structure that works on the center of gravity. 


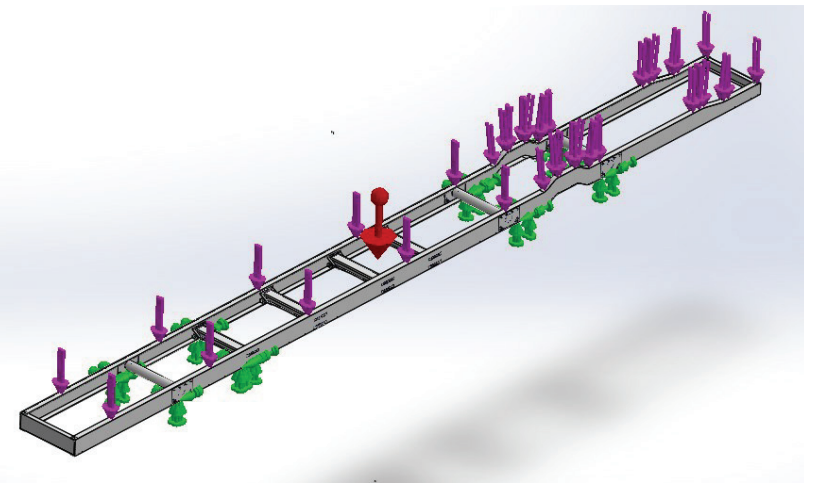

Fig. 12. Support and Load Mode of EV-Bus Chassis

\section{2. 2. Meshing on Chassis Ladder Frame}

After modeling the support and loading, the material selection in the previous stage, meshing is performed on the CAD software before finite element analysis is carried out for static analysis of the chassis. The meshing results are shown in Fig. 13.

In Fig. 13, it is shown how this CAD software produces meshing. This meshing process can be repeated in the simulation process if there is a running error in the analysis later. There is usually an imperfect form of the contact element. This figure is shown on the joints and on the parts that occur with a high concentration of holes and other bends.

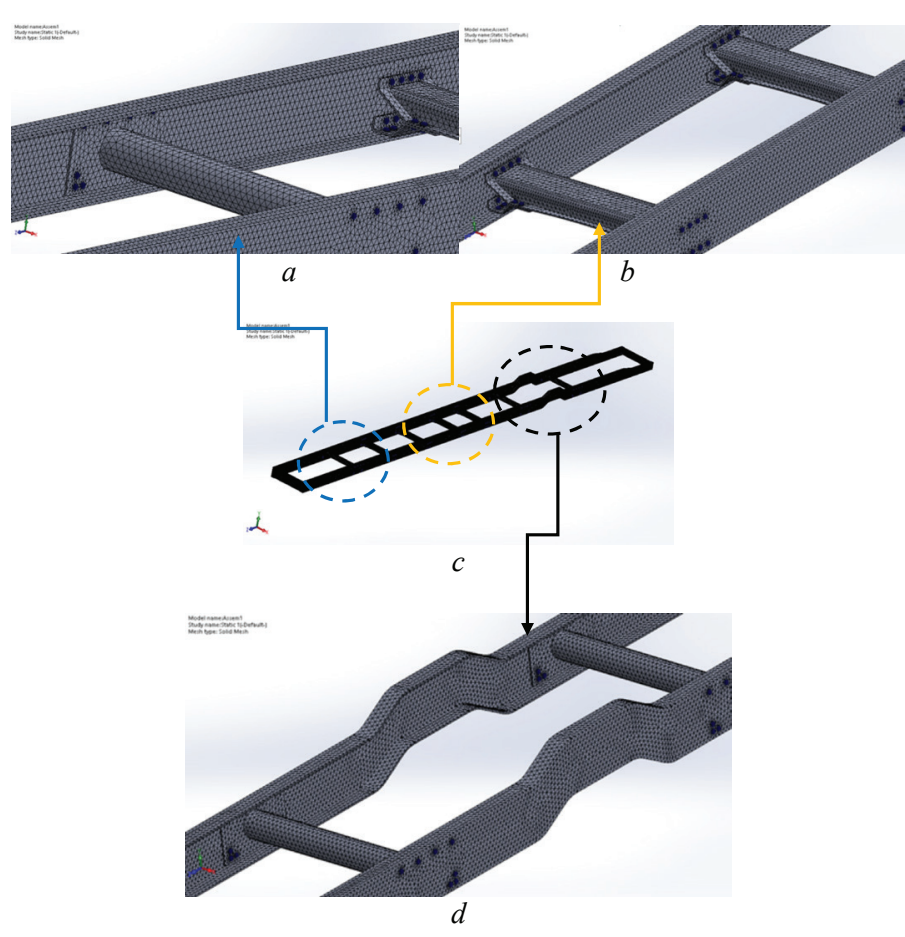

Fig. 13. Meshing of Chassis Frame: $a-$ front Section; $b-$ middle Section; $c$ - main Chassis Frame; $d$ - rear Section

\section{2. 3. Stress Analysis of Chassis Frame}

Static analysis is performed by carrying out static loading on the chassis structure with the results in CAD software as follows.

The von Mises result of the CAD software's chassis stress has a maximum value of $75.8 \mathrm{MPa}$ (Fig. 14) with a theoretical value of $72.33 \mathrm{MPa}$ (eq. 17). The difference in value is not far enough, so the simulation results for this stress value can be accepted with the given loading conditions and the meshing process.

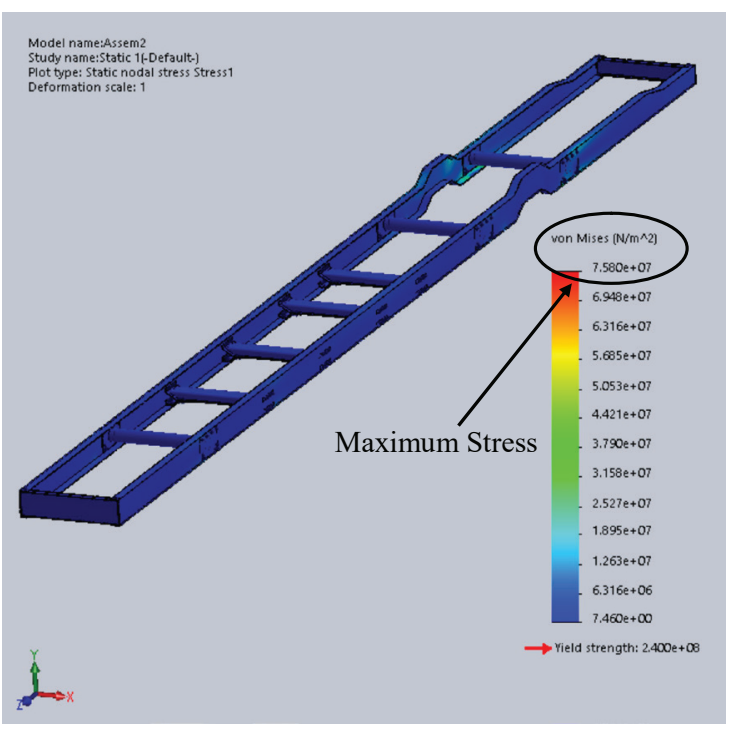

Fig. 14. Stress (von Mises) contour of Chassis Frame

The maximum deflection of static analysis in CAD software is $2,568 \mathrm{~mm}$ (Fig. 15) with a theoretical value of $2,594 \mathrm{~mm}$ (eq. (18)). The investigation is also in line with the stress results in this chassis structure, which do not show significant results.

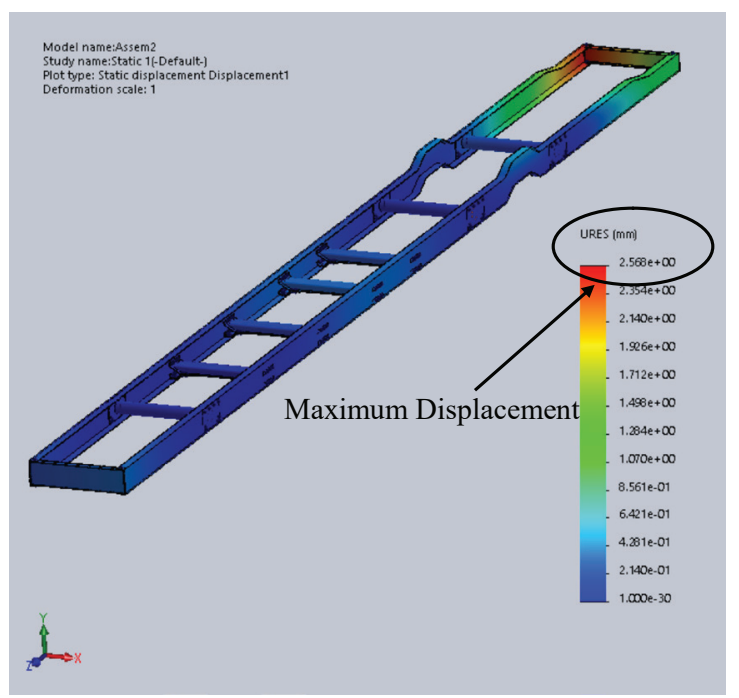

Fig. 15. Displacement Contour of Chassis Frame

No less important thing to note in cross-checking the results of design and simulation is safety. The simulation results in this CAD software with static analysis obtained the least security factor of 3.2 as seen in Fig. 16. The research is considered to be enough acceptable design results [16] by doing this SS400 steel input material.

The chassis with local SS400 material is considered acceptable because the difference between theoretical and numerical results is not too large. Further research is carried out by comparing other local uses or variations in the number of cross-member beams and different types of chassis, monocoque, or low-deck chassis. Dynamic loads can also increase this type of loading by incorporating bus speed elements under various road conditions. 


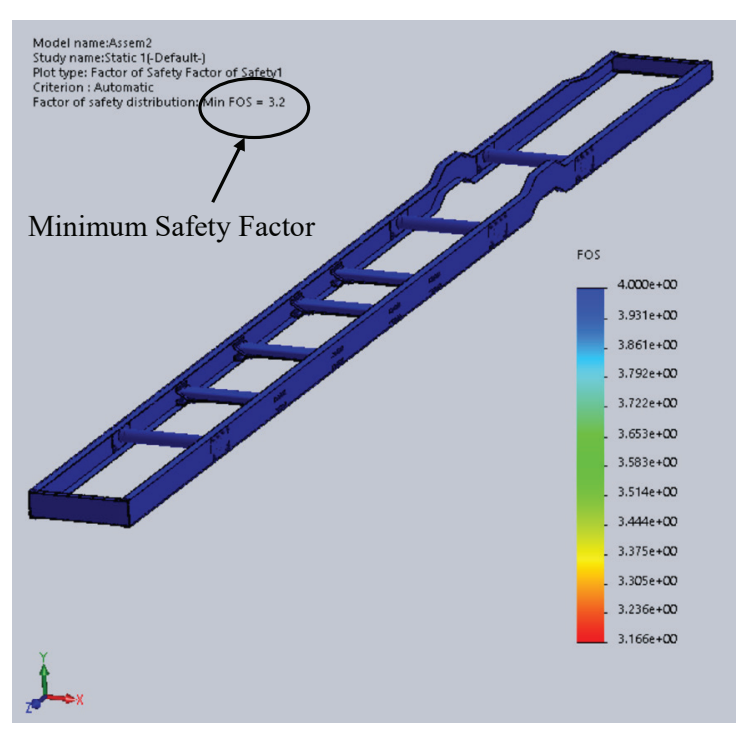

Fig. 16. Safety Factor Contour of Chassis Frame

\section{2. 4. Results of Theoretical analysis}

By using equations (1) to (13), the results of theoretical calculations are presented in Table 1.

Table 1

Resume of Theoretical Results

\begin{tabular}{|c|c|c|}
\hline No. & Item & Value \\
\hline 1 & The support reaction & $\begin{array}{l}R_{c}=29,543.89 \mathrm{~N} \\
R_{D}=40,107.71 \mathrm{~N}\end{array}$ \\
\hline 2 & $\begin{array}{l}\text { The shear force and } \\
\text { bending moment }\end{array}$ & $\begin{array}{c}V_{1}=14,204.79 \mathrm{~N} \\
V_{2}=15,339.1 \mathrm{~N} \\
V_{4}=19,636.04 \mathrm{~N} \\
V_{3}=20,471.67 \mathrm{~N}\end{array}$ \\
\hline 3 & The Bending Moment & $\begin{array}{c}M_{1}=-16,903,702.5 \mathrm{~N} \cdot \mathrm{mm}, \\
M_{2}=-32,301,279.2 \mathrm{~N} \cdot \mathrm{mm}, \\
M_{3}=2,807,436.8 \mathrm{~N} \cdot \mathrm{mm}, \\
M_{\max }=2,807,436.8 \mathrm{~N} \cdot \mathrm{mm}\end{array}$ \\
\hline 4 & $\begin{array}{l}\text { The moment of inertia } \\
\text { for the main beam }\end{array}$ & $\begin{array}{l}I_{x x}=20,002,474.7 \mathrm{~mm}^{4} \\
I_{b 1}=20,002,474.7 \mathrm{~mm}^{4} \\
I_{b 2}=20,002,474.7 \mathrm{~mm}^{4}\end{array}$ \\
\hline 5 & $\begin{array}{l}\text { The moment of inertia } \\
\text { for the cross member } \\
\text { beam }\end{array}$ & $\begin{array}{c}I_{b 3}=1,096,270.67 \mathrm{~mm}^{4} \\
I_{b 4}=2,813,829.36 \mathrm{~mm}^{4} \\
I_{b t}=50,017,690.8 \mathrm{~mm}^{4}\end{array}$ \\
\hline 6 & The main stress & $\sigma=72.33 \mathrm{MPa}$ \\
\hline 7 & $\begin{array}{l}\text { The deflection of beam } \\
\text { overhangs with distrib- } \\
\text { uted loads }\end{array}$ & $y=-2.594 \mathrm{~mm}$ \\
\hline
\end{tabular}

The results in Table 1 will be combined with the results of static analysis with CAD software to assess the suitability of the SS400 material for the EV-Bus chassis material. The most important values in this table are the stress value of $72.33 \mathrm{MPa}$ and the deflection value of $2,594 \mathrm{~mm}$.

\section{Discussion of the research results}

This research was conducted to complement the entire EV-Bus type research at the University of Indonesia. Previously, the type of EV-Bus that has been successful as in Fig. 1 is the conversion of ICE-Bus. The type of chassis used is that of a certain bus brand with the R260 type. This type of chassis is what reverse engineering is doing in this study, resulting in a rolling chassis as shown in Fig. 11.

The approach taken in this research is in the form of theoretical analysis and numerical analysis. Theoretical analysis with the chassis structure with a beam structure with two overhangs. Numerical analysis was carried out from the rolling model of the chassis with two main beams and four cross member beams and two hollow beams. The difference or error that occurs from these two approaches is quite small, namely $4.5 \%$ for stress and $1 \%$ for deflection. This small difference in numerical and theoretical results has been accepted in the redesign of the EV-Bus ladder frame. This result is better than what has been done on the Eicher E2 chassis where the difference between theoretical and analysis software is $10 \%$ and the deflection is more than $5.92 \%$ [13].

From the material selection process, the SS400 with the most important mechanical properties is the tensile strength of $480 \mathrm{MPa}$. The maximum stress result with CAD software is $75.8 \mathrm{MPa}$ as shown in Fig. 14, while the theoretical calculation result is $72.33 \mathrm{MPa}$ as in Table 1. From the comparison of the tensile strength and stress that occurs, it produces a safety factor of 3.2 as in Fig. 16. With this result, the SS400 is a feasible material type as the ladder frame structure material for the EV-Bus.

The limitation of this research is in the form of a theoretical approach with a $2 \mathrm{D}$ beam model while the results of numerical analysis using CAD software with a 3D model. So it is necessary for further research in an experiment by a certain scale model to validate the results of both approaches. Later, after these three approaches are successful, namely theoretical, numerical and certain scales leading to valid results, the production process of the EV-Bus ladder frame with this SS400 material.

\section{Conclusions}

1. Reverse engineering method has been successfully redesigned a chassis for EV-Bus with two main beams and four cross member beams, and two hollow cross beams. This is obtained from the difference between static analysis with software and quite small theoretical studies, namely $4.5 \%$ for stress and $1 \%$ for deflection.

2. Static analysis of the chassis structure uses distributed load with a total of $14200 \mathrm{~kg}$. With using material type SS400 with an elasticity modulus of $190 \mathrm{GPa}$ and tensile strength of $480 \mathrm{MPa}$. From the static analysis by CAD software, the von Mises stress occurred is $75.8 \mathrm{MPa}$ and maximum deflection is $2.568 \mathrm{~mm}$ and the smallest safety factor is 3.2 . This result shows the local material SS 400 chances the criteria as material for the EV-Bus chassis structure later.

\section{Acknowledgments}

The authors are grateful to the University of Indonesia through the "PUTI Doktor UI 2020" scheme with 
contract number NKB-678/UN2.RST/HKP.05.00/2020 and the Indonesian government through the Indonesian
Endowment Fund for Education (LPDP) for funding this research.

\section{References}

1. Thomas, J. (2014). Drive Cycle Powertrain Efficiencies and Trends Derived from EPA Vehicle Dynamometer Results. SAE International Journal of Passenger Cars - Mechanical Systems, 7 (4), 1374-1384. doi: https://doi.org/10.4271/2014-01-2562

2. Lohse-Busch, H., Duoba, M., Rask, E., Stutenberg, K., Gowri, V., Slezak, L., Anderson, D. (2013). Ambient Temperature (20 F, $72^{\circ} \mathrm{F}$ and $95^{\circ} \mathrm{F}$ ) Impact on Fuel and Energy Consumption for Several Conventional Vehicles, Hybrid and Plug-In Hybrid Electric Vehicles and Battery Electric Vehicle. SAE Technical Paper Series. doi: https://doi.org/10.4271/2013-01-1462

3. Rhodes, K., Kok, D., Sohoni, P., Perry, E., Kraska, M., Wallace, M. (2017). Estimation of the Effects of Auxiliary Electrical Loads on Hybrid Electric Vehicle Fuel Economy. SAE Technical Paper Series. doi: https://doi.org/10.4271/2017-01-1155

4. Carlson, R. B., Wishart, J., Stutenberg, K. (2016). On-Road and Dynamometer Evaluation of Vehicle Auxiliary Loads. SAE International Journal of Fuels and Lubricants, 9 (1), 260-268. doi: https://doi.org/10.4271/2016-01-0901

5. $\quad$ Ayu, W. (2016). UI Perkenalkan Mobil Listrik di Dies Natalis ke-52 FTUI.

6. Milliken, W. F., Milliken, D. L. (2002). Chassis Design. SAE International, 676. doi: https://doi.org/10.4271/r-206

7. Crolla, D. A. (Ed.) (2009). Automotive engineering: powertrain, chassis system and vehicle body. Butterworth-Heinemann, 827.

8. Mahmoodi-k, M., Davoodabadi, I., Višnjić, V., Afkar, A. (2014). Stress and dynamic analysis of optimized trailer chassis. Tehnički vjesnik: znanstveno-stručni časopis tehničkih fakulteta Sveučilišta u Osijeku, 21 (3), 599-608.

9. Rajappan, R., Vivekanandhan, M. (2013). Static and modal analysis of chassis by using FEA. The International Journal Of Engineering And Science, 2 (2), 63-73.

10. Renuke, P. A. (2012). Dynamic analysis of a car chassis. International Journal of Engineering Research and Applications, 2 (6), 955-959.

11. Patel, V. V., Patel, R. I. (2012). Structural analysis of a ladder chassis frame. World Journal of Science and Technology, 2 (4), 5-8.

12. Singh, A., Soni, V., Singh, A. (2014). Structural analysis of ladder chassis for higher strength. International Journal of Emerging Technology and Advanced Engineering, 4 (2), 253-259.

13. Francis, V., Rai, R. K., Singh, A. K., Singh, P. K., Yadav, H. (2014). Structural Analysis of Ladder Chassis Frame for Jeep Using Ansys. International Journal Of Modern Engineering Research (IJMER), 4 (4), 41-47.

14. Patil, H. B., Kachave, S. D., Deore, E. R. (2013). Stress Analysis of Automotive Chassis with Various Thicknesses. IOSR Journal of Mechanical and Civil Engineering, 6 (1), 44-49. doi: https://doi.org/10.9790/1684-0614449

15. Chandra, M. R., Sreenivasulu, S., Hussain, S. A. (2012). Modeling and Structural analysis of heavy vehicle chassis made of polymeric composite material by three different cross sections. International Journal of Modern Engineering Research (IJMER), 2 (4), $2594-2600$.

16. Siregar, R., Adhitya, M., Sumarsono, D. A., Nazaruddin, Heryana, G., Zainuri, F. (2020). Study the brake performance of a passenger car based on the temperature that occurs in each brake unit. RECENT PROGRESS ON: MECHANICAL, INFRASTRUCTURE AND INDUSTRIAL ENGINEERING: Proceedings of International Symposium on Advances in Mechanical Engineering (ISAME): Quality in Research 2019. doi: https://doi.org/10.1063/5.0003747

17. Adhitya, M., Siregar, R., Sumarsono, D. A., Nazaruddin, N., Heryana, G., Prasetyo, S., Zainuri, F. (2020). Experimental analysis in the test rig to detect temperature at the surface disc brake rotor using rubbing thermocouple. Eastern-European Journal of Enterprise Technologies, 2 (5 (104)), 6-11. doi: https://doi.org/10.15587/1729-4061.2020.191949

18. Nazaruddin, N., Syehan, A., Heryana, G., Adhitya, M., Sumarsono, D. A. (2019). Mode Shape Analysis of EV-Bus Chassis with Reverse Engineering Method. IOP Conference Series: Materials Science and Engineering, 694, 012002. doi: https://doi.org/ $10.1088 / 1757-899 x / 694 / 1 / 012002$

19. Solghar, A. A., Arsalanloo, Z. (2013). The Stress Analysis of Minibus Chassis Using Finite Element Method. Caspian Journal of Applied Sciences Research, 2 (5), 20-25.

20. Rajasekar, K., Saravanan, R. (2014). Literature Review on Chassis Design of On-Road Heavy Vehicles. International Journal of Innovative Science, Engineering \& Technology, 1 (7), 428-433. 